\title{
Social valuation of ecosystem services in mountain regions
}

\author{
Ariane Walz $^{1}$ (1) Adrienne Grêt-Regamey $^{2} \cdot$ Sandra Lavorel $^{3}$
}

Received: 3 July 2016/Accepted: 9 July 2016/Published online: 8 September 2016

(C) Springer-Verlag Berlin Heidelberg 2016

Mountain areas worldwide are considered critical regions for ecosystem services provision (Grêt-Regamey et al. 2012). The diverse mountain landscapes support a large variety of ecosystems services, such as energy, water, food, protection from natural hazards, and multiple cultural ecosystem services (Huber et al. 2013; Crouzat et al. 2015). They provide these services to people living in the mountain regions themselves and their neighbouring lowlands, as well as to people coming into the mountains, in particular to enjoy cultural ecosystem services, and generating income through tourism there. To sustainably manage mountain regions and their natural resources, the value of ecosystem services to the diverse beneficiaries needs to be understood and accounted for.

Non-monetary social valuation has been considered a powerful approach to elicit the importance of ecosystem services to diverse beneficiaries in a non-market value elicitation context (De Groot et al. 2010). Such social valuation can be valuable in particular to understand beneficiarieś perception of ecosystem service (Lamarque et al. 2011), their demands and preferences (Martín-López et al. 2014) as well as potential conflicts between groups of beneficiaries (Castro et al. 2011). All three aspects are considered crucial to achieve sustainable, self-organising

Ariane Walz

Ariane.Walz@uni-potsdam.de

1 Institute of Earth and Environmental Science, University of Potsdam, Karl-Liebknecht-Straße 24-25, 14476 Potsdam, Germany

2 ETH Zürich, Institute for Spatial and Landscape Planning, Stefano-Franscini-Platz, 58093 Zurich, Switzerland

3 Laboratoire d'Ecologie Alpine, CNRS - Université Grenoble Alpes, CS 40700, 38058 Grenoble Cedex 9, France socio-ecological systems in the long run (Ostrom 2009). Besides deliberative qualitative social valuation techniques (e.g. Wilson and Howarth 2002; Chan et al. 2012) and crowd-sourcing (Tenerelli et al. 2016), questionnaire and interview-based methods have proven appropriate means to elicit social values, as they compromise between the number of people included and the generation of specific knowledge through tailor-made questions (e.g. OterosRozas et al. 2014; Martín-López et al. 2012).

In this special issue on ecosystem services in mountain regions, we bring together four studies that apply such social valuation methods in the European Alps and the Rocky Mountains. Interviewees were asked to identify main ecosystem services, and to rank and value them according to their personal perspective. Zoderer et al. (2015) and Bagstad et al. (2015) focus on the value for the greater public of mountain ecosystem services, whereas Sarkki et al. (2015) and Haida et al. (2015) explore expert opinions. They all build on empirical data based on questionnaire surveys or well-structured face-to-face interviews and aim to elicit society's perception and value of mountain landscapes at a regional level.

Zoderer et al. (2015) interviewed more than 500 tourists to value ecosystem services that are provided by three different landscapes in Southern Tyrol, Italy. The overall result shows different values assigned to the three landscape types, with regulating services valued on average highest in all three landscapes. The highest values in cultural services were assigned to the open woodlands provided by traditional larch meadows. Differences in the attributed values could be explained mainly by the origin of the tourists as well as their self-stated environmental knowledge.

Bagstad et al. (2015) compared the spatially modelled social value of visitors to a National Forest in the Southern 
Rocky Mountains (by SolVES) with the outcome of biophysical modelling of the same ecosystem services (by ARIES), including aesthetic value, biodiversity, soil erosion and water provisioning. Their results show that the areas highly valued by the public do not necessarily overlap with the areas that show the greatest biophysical capacity to provide these services. They identified shortcomings in the user perception-based supply mapping of ecologically more complex services and emphasise the complementarity of information sources in ecosystem service assessment. Finally, they highlight the added-value of public opinion to advance regionally feasible solutions in ecosystem services-based resource management.

Sarkki et al. (2015) evaluated expert opinions on key ecosystem services supplied by treeline ecosystems in fifteen European countries, related benefits and threats as well as governance instruments. The results from the expert panel revealed that altitudinal treelines within cultural landscapes provide more ecosystem services than polar treelines. Main beneficiaries from treeline ecosystem services include science and education, nature conservation and tourism. Depending on their impact on the treeline ecosystems, Sarkki et al. (2015) introduce a topology of beneficiaries, including "green key players", the "harmless crowd", "occasional stressors" and "risky users". Finally, governance instruments were found to be well established, in particular for the altitudinal treelines.

Haida et al. (2015) investigated the perception and ranking of ecosystem services of a range of experts for three mountain regions in Austria and Italy. Their results indicate the strong relevance of water provisioning, habitat, energy supply, food provisioning and regulating natural hazards for these regions. They further show the high variability within the expertś opinions, which could not be attributed to differences between the regions or in the expertise of the interview partners, and finally highlight research gaps by comparing the identified ranking with the scientific literature.

All four articles demonstrate the potential and importance of including social values in ecosystem services assessments. In line with Chan et al. (2016), all studies reveal important insights into the appreciation of cultural ecosystem services, with partly surprisingly results (e.g. the high value for larch meadows, Zoderer et al. 2015, versus the relative low ranking in Haida et al. 2015). This ability to account for cultural ecosystem services is a strong advantage for many mountain regions, as they play an important role in touristic and traditional cultural mountain landscapes.

Furthermore, all four studies indicate the strong overall perception and appreciation of mountain regions as wildlife habitats, and the mountain ecosystemś role in regulating material and water flows. Depending on the region, also food and water provisioning were highly ranked. However, they also indicate how strongly values differ between mountain regions and beneficiaries and that transferring results from one study to the other might not be an adequate procedure to elicit the specifics of a mountain region (Haida et al. 2015; Zoderer et al. 2015).

They further illustrate a range of purposes that social valuation studies can serve from quantifying social value of ecosystem services for different locations and between ecosystems (Bagstad et al. 2015; Zoderer et al. 2015); exploring perception and knowledge on the regional socio-ecological system (Sarkki et al. 2015; Bagstad et al. 2015); and identifying differing priorities between beneficiaries (Haida et al. 2015; Zoderer et al. 2015). Further, social valuation is seen highly complementary to biophysical modelling of ecosystem services with a great potential to identify feasible, potentially synergetic solutions in natural resource management (Bagstad et al. 2015.

Moreover, the four articles give useful methodological insights on choices of techniques and addressees beyond the regional case studies. For example, they indicate that concrete examples and location can strongly support social valuation in highly heterogeneous mountain landscapes (Zoderer et al. 2015; Bagstad et al. 2015).

Finally, they show limitations of questionnaire and interview-based valuation, for instance, in identifying and mapping ecosystem services, in particular when it comes to supply of regulative and supportive ecosystem services and less well-known areas (Bagstad et al. 2015).

This special issue was initiated at the workshop on "Qualities, Vulnerabilities, and Management of Ecosystem Services in Mountain Regions Worldwide", which took place on 11-13 September 2012 in Möschberg, Switzerland, and was funded by the Mountain Research Initiative.

\section{References}

Bagstad KJ, Reed JM, Semmens DJ, Sherrouse BC, Troy A (2015) Linking biophysical models and public preferences for ecosystem service assessments: a case study for the Southern Rocky Mountains. Reg Environ Change 16(7):2005-2018. doi:10.1007/ s10113-015-0756-7

Castro AJ, Martín-López B, García-Llorente M, Aguilera PA, López E, Cabello J (2011) Social preferences regarding the delivery of ecosystem services in a semiarid Mediterranean region. J Arid Environ 75(11):1201-1208. doi:10.1016/j.jaridenv.2011.05.013

Chan KM, Guerry AD, Balvanera P, Klain S, Satterfield T, Basurto X, Bostrom A, Chuenpagdee R, Gould R, Halpern BS, Hannahs N (2012) Where are cultural and social in ecosystem services? A framework for constructive engagement. BioScience 62(8):744-756. doi:10.1525/bio.2012.62.8.7 
Chan KM, Balvanera P, Benessaiah K, Chapman M, Díaz S, GómezBaggethun E, Gould R, Hannahs N, Jax K, Klain S, Luck GW (2016) Opinion: why protect nature? Rethinking values and the environment. Proc Natl Acad Sci 113(6):1462-1465. doi:10. 1073/pnas.1525002113

Crouzat E, Mouchet M, Turkelboom F, Byczek C, Meersmans J, Berger F, Verkerk PJ, Lavorel S (2015) Assessing bundles of ecosystem services from regional to landscape scale: insights from the French Alps. J Appl Ecol 52(5):1145-1155. doi:10. 1111/1365-2664.12502

De Groot RS, Alkemade R, Braat L, Hein L, Willeme L (2010) Challenges in integrating the concept of ecosystem services and values in landscape planning, management and decision making. Ecol Complex 7(3):260-272. doi:10.1016/j.ecocom.2009.10.006

Grêt-Regamey A, Brunner SH, Kienast F (2012) Mountain ecosystem services: who cares. Mt Res Dev 32S1:23-34. doi:10.1659/ MRD-JOURNAL-D-10-00115.S1

Haida C, Rüdisser J, Tappeiner U (2015) Ecosystem services in mountain regions: experts' perceptions and research intensity. Reg Environ Change 16(7):1989-2004. doi:10.1007/s10113015-0759-4

Huber R, Rigling A, Bebi P, Brand FS, Briner S, Buttler A, Elkin C, Gillet F, Grêt-Regamey A, Hirschi C, Lischke H (2013) Sustainable land use in mountain regions under global change: synthesis across scales and disciplines. Ecol Soc 18(3):20. doi:10.5751/ES-05499-180336

Lamarque P, Tappeiner U, Turner C, Steinbacher M, Bardgett RD, Szukics U, Schermer M, Lavorel S (2011) Stakeholder perceptions of grassland ecosystem services in relation to knowledge on soil fertility and biodiversity. Reg Environ Change 11(4):791-804. doi:10.1007/s10113-011-0214-0

Martín-López B, Iniesta-Arandia I, García-Llorente M, Palomo I, Casado-Arzuaga I, Del Amo DG, Gómez-Baggethun E, OterosRozas E, Palacios-Agundez I, Willaarts B, González JA (2012)
Uncovering ecosystem service bundles through social preferences. PLoS One 7(6):e38970. doi:10.1371/journal.pone. 0038970

Martín-López B, Gómez-Baggethun E, García-Llorente M, Montes C (2014) Trade-offs across value-domains in ecosystem services assessment. Ecol Ind 37:220-228. doi:10.1016/j.ecolind.2013. 03.003

Ostrom E (2009) A general framework for analyzing sustainability of social-ecological systems. Science 325(5939):419-422. doi:10. 1126/science. 1172133

Oteros-Rozas E, Martín-López B, González JA, Plieninger T, López CA, Montes C (2014) Socio-cultural valuation of ecosystem services in a transhumance social-ecological network. Reg Environ Change 14(4):1269-1289. doi:10.1007/s10113-0130571-y

Sarkki S, Ficko A, Grunewald K, Nijnik M (2015) Benefits from and threats to European treeline ecosystem services: an exploratory study of stakeholders and governance. Reg Environ Change 16(7):2019-2032. doi:10.1007/s10113-015-0812-3

Tenerelli P, Demšar U, Luque S (2016) Crowdsourcing indicators for cultural ecosystem services: a geographically weighted approach for mountain landscapes. Ecol Ind 64:237-248. doi:10.1016/j. ecolind.2015.12.042

Wilson MA, Howarth RB (2002) Discourse-based valuation of ecosystem services: establishing fair outcomes through group deliberation. Ecol Econ 41(3):431-443. doi:10.1016/S09218009(02)00092-7

Zoderer BM, Lupo Stanghellini PS, Tasser E, Walde J, Wieser H, Tappeiner U (2015) Exploring socio-cultural values of ecosystem service categories in the Central Alps: the influence of sociodemographic factors and landscape type. Reg Environ Change 16(7):2033-2044. doi:10.1007/s10113-015-0922-y 